\title{
Expression of miR-34a in cataract rats and its related mechanism
}

\author{
CAIMEI XIU, JING JIANG and RUIYING SONG \\ Department of Ophthalmology, The Affiliated Yantai Yuhuangding Hospital of Qingdao University, \\ Yantai, Shandong 264000, P.R. China
}

Received September 13, 2019; Accepted November 12, 2019

DOI: $10.3892 /$ etm.2019.8295

\begin{abstract}
Expression of miR-34a in cataract rats and its related mechanism were investigated. A total of $30 \mathrm{SD}$ rats were selected and divided into three groups: group A: 2-month-old lucent lens, group B: 18-month-old lucent lens, and group C: 18-month-old naturally occurring cataract lens. The lens was taken and measured by LOC III to determine the degree of lens opacity of the three groups of rats. qPCR was used to detect expression of miR-34a and mRNA of SIRT1 and P53. Western blotting was used to detect the protein expression of SIRT1 and P53. Cell apoptosis was detected by flow cytometry. The lens of rats in group $\mathrm{C}$ was more turbid than that of groups $\mathrm{A}$ and $\mathrm{B}$ $(\mathrm{P}<0.05)$. The expression levels of miR-34a and P53 mRNA in the rats lens of group $C$ were significantly higher than those in groups $\mathrm{A}$ and $\mathrm{B}$, and the expression of SIRT1 mRNA was significantly lower than that of groups A and group $B(P<0.05)$. Expression of miR-34a in group $A$ was significantly higher than that in group $B$, the mRNA expression of SIRT1 was significantly lower than that in the lucent lens of 18 -month-old rats $(\mathrm{P}<0.05)$. The expression of SIRT1 protein in group $\mathrm{C}$ was significantly lower than that in groups A and group B, while the expression level of P53 protein in group C was significantly higher than that of groups A and B. The expression of SIRT1 protein in group B was significantly higher than that in group A $(\mathrm{P}<0.05)$. The apoptosis rate of group $\mathrm{C}$ was higher than that of groups A and group B $(\mathrm{P}<0.05)$. In conclusion, the upregulation of expression level of miR-34a is related to cataract occurrence in rats, which may be caused by regulation of SIRT1 protein.
\end{abstract}

Correspondence to: Dr Ruiying Song, Department of Ophthalmology, The Affiliated Yantai Yuhuangding Hospital of Qingdao University, 20 Yudong Road, Yantai, Shandong 264000, P.R. China E-mail: rqv5w9@163.com

Key words: miR-34a, SIRT1, P53, cataract rats, expression, mechanism

\section{Introduction}

Cataract is the most common cause of blindness worldwide and is closely related to age, and oxidative stress and subsequent formation of reactive oxygen species (ROS) are considered to be the main cause of age-related cataract (1). Its pathogenesis involves environmental exposure and genomic mutations that alter epigenetic patterns, and microRNA is one of them. Studies have found evidence that miRNAs are involved in a variety of cellular functions, such as cell proliferation, apoptosis, stress response and aging. A great deal of research has been carried out on the mechanism of miRNA action in cancer cells, blood and muscle tissues (2-5). It was found in a study on cataract that MicroRNA-34a, hereinafter referred to as miRNA-34a, decreased rapidly in the lucent lens among the 32 miRNAs that were significantly expressed in the central epithelial cells of the lucent lens and the cataract lens (6), indicating that miRNA-34a was closely related to the pathogenesis of cataract.

miR-34a is associated with many diseases, for example, it can inhibit the proliferation and migration of smooth muscle cells in vascular diseases to reduce the formation of neointima (7), inhibit invasion and metastasis by targeting tgif 2 in gastric cancer (8), and interfere with the cell cycle and apoptosis through P53 pathway to play a role in regulating aging (9). Studies have found that miR-34a can also inhibit the expression of silencing information regulator 1 (SIRT1). SIRT1 has an important protective effect on $\mathrm{H}_{2} \mathrm{O}_{2}$-induced apoptosis of lens epithelial cells, and its decreased expression is related to the severity of cataract (10). In addition, some studies supported that the expression level of miR-34a was positively correlated with the age, scores of $\mathrm{N}, \mathrm{C}$ and $\mathrm{P}$ of cataract patients. The N, C and P scores are the degree of lens opacity, and the nuclear $(\mathrm{N})$, cortical $(\mathrm{C})$ and posterior subcapsular $(\mathrm{P})$ cataract scores were graded according to the improved lens opacity grading system. Elderly patients had higher $\mathrm{N}, \mathrm{C}$ and $\mathrm{P}$ scores. It indicates that the high level of miR-34a is related to the high degree of lens opacity and severe lens aging (11). Based on the above, we hypothesized that the upregulation of expression level of miR-34a was associated with occurrence of cataract, and the occurrence of cataract might be caused by the regulation of SIRT1 protein, and the older the age, the higher the upregulation of expression level of miR-34a. This experiment aimed to verify the 
expression of miR-34a in cataract and its related mechanism through the rat model.

\section{Materials and methods}

Selection of experimental animals. Thirty SD rats with 30 eyes (purchased from Shilaike Jingda Experimental Animal Co. Ltd.) were selected and divided into three groups: group A: 2-month-old lucent lens, 10 rats with 10 eyes; group B: 18-month-old lucent lens, 10 rats with 10 eyes; group C: naturally occurring cataract lens at 18-month-old, 10 rats with 10 eyes. Group A weighed 160-200 g, group B weighed 390-420 g, group C weighed 390-420 g, and they were fed for $60 \mathrm{~h}$ under the same feeding conditions.

The study was approved by the Ethics Committee of The Affiliated Yantai Yuhuangding Hospital of Qingdao University (Yantai, China).

Preparation of lens in rats. The rats were sacrificed by dislocation, then the corneas were cut open with scissors along the corneas of the rats at $360^{\circ}$. The lens was completely extracted, and then immediately put into the EP tube and stored at temperature of $-80^{\circ} \mathrm{C}$. After the severity of lens opacity, the cells were separated. Part of cells were made into homogenate to detect the expression of mRNA and protein, and another part was sent for primary culture to measure apoptosis rate.

Monitoring indicators. LOC III was used to analyze the severity of lens opacity. LOC III (12) was used to classify the degree of cataract opacity in the nucleus $(\mathrm{N})$, cortex $(\mathrm{C})$ and posterior subcapsular $(\mathrm{P})$ of the lens of rats in the three groups to determine the severity of cataract. Nuclear $(\mathrm{N})$ opacity included 4 levels in total: 0 level: nuclear transparency, the embryo nucleus could be clearly seen. N1, early nuclear opacity; N2, moderate nuclear opacity; N3, severe nuclear opacity. The cortex $(\mathrm{C})$ was divided into seven categories: $\mathrm{C} 0$, cortical transparency. $\mathrm{C} 1$, a small amount of dot opacity; $\mathrm{C} 1$, enlarged dot opacity range; $\mathrm{C} 2$, a small amount of dot opacity in the pupil area; $\mathrm{C} 3$, wheel-like opacity in cortex which was over the second quadrant; $\mathrm{C} 4$, enlarged cortical wheel-like opacity, with $\sim 50 \%$ pupil area in opacity. C5, $\sim 90 \%$ of the cortical area in opacity, degree of opacity in $\mathrm{C} 5$ exceeded C4. Posterior subcapsular (P) was classified into 5 levels: P0, posterior subcapsular transparency; $\mathrm{P} 1, \sim 3 \%$ posterior subcapsular opacity. $\mathrm{P} 2, \sim 30 \%$ posterior subcapsular opacity; P3, $50 \%$ of posterior capsular opacity; P4, opacity exceeded P3.

The expression level of miR-34a and mRNA of SIRT1 and P53 in the three groups were detected by qPCR. Total RNA was extracted firstly: $\sim 50 \mathrm{mg}$ of tissue was put into a $1.5 \mathrm{ml}$ RNAse-free centrifuge tube. TRIzol $(0.5 \mathrm{ml})$ was added into and grinded to homogenate with a homogenizer. Then TRIzol $(0.5 \mathrm{ml})$ was added and left standing for $\sim 0.5 \mathrm{~h}$. Then adding $200 \mu \mathrm{l}$ of chloroform per $1 \mathrm{ml}$ of TRIzol, mixed gently for $30 \mathrm{sec}$ and placed on ice for $5 \mathrm{~min}$. Then centrifuged at $1,500 \mathrm{x} \mathrm{g}$ at $4^{\circ} \mathrm{C}$ for $15 \mathrm{~min}$. Approximately $400-600 \mu \mathrm{l}$ of the supernatant was transfered to a new centrifuge tube with a pipette, then $500 \mu \mathrm{l} / 1 \mathrm{ml}$ TRIzol of isopropanol was added, covered, mixing by inversion and left standing for $10 \mathrm{~min}$. It was centrifuged at $4^{\circ} \mathrm{C}$, at $1,500 \mathrm{x}$ g for $10 \mathrm{~min}$. Discarding supernatant, absorbed isopropanol was added with $1 \mathrm{ml}$ of $75 \%$ ethanol fully mixing. The RNA was washed at $1,500 \mathrm{xg}$ for $10 \mathrm{~min}$ at $4^{\circ} \mathrm{C}$. Discarding the supernatant, dried naturally for 5-10 min, and $20 \mu \mathrm{l}$ of DEPC water was added to fully dissolve the total RNA. qPCR was performed, and the primers were designed by Shanghai Sangon Biotech Co., Ltd. The sense and reverse primers are shown in Table I. Comparing the ratio of the three groups to the internal reference $\beta$-actin, the levels of the three groups of mRNA were obtained. The details were: Pre-denaturation at $95^{\circ} \mathrm{C}$ for $5 \mathrm{~min}$, denaturation at $95^{\circ} \mathrm{C}$ for $15 \mathrm{sec}$, annealing at $60^{\circ} \mathrm{C}$ for $30 \mathrm{sec}$, with a total of 40 cycles at $60-95^{\circ} \mathrm{C}$.

Western blotting was used to detect the expression of SIRT1 and P53 protein in the three groups. The liquid chlorine was added when grinding the tissues and the RIM cell lysis buffer was added in a certain proportion. The homogenate was crushed and centrifuged at a low temperature and high speed. The supernatant was taken and stored in the refrigerator at $-80^{\circ} \mathrm{C}$ after subpackaging. The expression levels of SIRT1 and P53 proteins were detected by western blotting, and the ratios of SIRT1/GAPDH and P53/GAPDH represented the relative expression levels.

Apoptosis of lens epithelial cells was detected by flow cytometry. Apoptosis was detected using a cell apoptosis assay, and operated according to the instructions. BD FACSCalibur flow cytometry (purchased from Shanghai Pudi Biotechnology Co., Ltd.) was used to detect the cells transfected with Annexin V and PI in 6-well plates for $48 \mathrm{~h}$. The experiment was repeated 3 times.

Statistical methods. SPSS 18.0 was used for data analysis. The measurement data were expressed as mean \pm SD. Multivariate analysis was used to compare the differences among the groups and one-way ANOVA was used for testing. Enumeration data were qualified by chi-square test. $\mathrm{P}<0.05$ was considered statistically significant.

\section{Results}

Comparison of basic data of the three groups. The basic conditions of rats in group A, B and C were compared, such as weight, age, length, indoor temperature and indoor relative humidity. There was no significant difference between the indoor temperature for feeding and the indoor relative humidity $(\mathrm{P}>0.05)$. However, due to the different age of rats in the three groups, the length and weight of the group B and group $\mathrm{C}$ were significantly higher than that of A group $(\mathrm{P}<0.05)$ (Table II).

Comparison of LOC III classification of the three groups. In the classification of opacity degree of $\mathrm{N}$, there were 9 cases of N0, 1 case of N1, and no cases of N2 and N3 in group A. $\mathrm{N}$ score of group B was basically below N1, with 8 cases of $\mathrm{N} 0$ and 2 cases of N1, without N2 and N3. In group C, there were 2 cases of N0, 1 case of N1, 3 cases of $\mathrm{N} 2$ and 5 cases of N3. The opacity degree of $\mathrm{N}$ was higher in group $\mathrm{C}$ than in group $A$ and $B(P<0.05)$. In the classification of opacity degree of $\mathrm{C}$, there were 8 cases of $\mathrm{C} 0,1$ case of $\mathrm{C} 1$ in small amount of dot and 1 case in $\mathrm{C} 1$ with dot, no cases of 
Table I. Sense primer and reverse primer of miR-34a, mRNA and P53.

\begin{tabular}{lll}
\hline Factors & \multicolumn{1}{c}{ Sense primer } & \multicolumn{1}{c}{ Reverse primer } \\
\hline miR-34a & 5'-ATGGTTCG TGGGTGGCAGTGTCTTAGCTGG-3' & 5'-GCAGGGTCCGAGGTATTC-3' \\
SIRT1 & 5'-CCTTTCAGAACCACCAAAGCGGAA-3' & 5'-AGTCAGGTATCCCACAGGAAACAG-3' \\
P53 & 5'-GCCCATCCTTACCATCATCACG-3' & 5'-TTCTTCCTCTGTCCGACGGTCT3' \\
$\beta$-actin & 5'-ATACGCTGGGATGAGCACTGG-3' & 5'-TCTTTGCGGATGTCCACGTC-3'
\end{tabular}

${ }^{a} \mathrm{P}<0.05$, compared with group $\mathrm{C}$.

Table II. Basic data of four groups of rats mean \pm SD $(n=10)$.

\begin{tabular}{|c|c|c|c|c|c|}
\hline Groups & Group A & Group B & Group C & $\mathrm{F}$ & P-value \\
\hline Weight (g) & $168.23 \pm 11.24$ & $395.94 \pm 14.06$ & $407.23 \pm 12.78$ & 1119.00 & $<0.0001$ \\
\hline Length (cm) & $15.06 \pm 1.12$ & $18.52 \pm 1.42$ & $18.46 \pm 1.22$ & 24.73 & $<0.0001$ \\
\hline Indoor temperature $\left({ }^{\circ} \mathrm{C}\right)$ & $23.34 \pm 1.02$ & $23.78 \pm 0.97$ & $23.03 \pm 1.34$ & 1.13 & 0.338 \\
\hline Indoor relative humidity (\%) & $49.23 \pm 15.32$ & $48.83 \pm 16.42$ & $50.23 \pm 14.45$ & 0.022 & 0.978 \\
\hline
\end{tabular}

Table III. LOC III classification of the three groups $(n=10)$.

\begin{tabular}{|c|c|c|c|c|c|}
\hline Groups & Group A & Group B & Group C & $\chi^{2}$ & $\mathrm{P}$-value \\
\hline Grade of $\mathrm{N}$ & & & & 20.38 & 0.002 \\
\hline N0 & 9 & 8 & 1 & & \\
\hline $\mathrm{N} 1$ & 1 & 2 & 1 & & \\
\hline $\mathrm{N} 2$ & 0 & 0 & 3 & & \\
\hline N3 & 0 & 0 & 5 & & \\
\hline Grade of C & & & & 27.76 & 0.006 \\
\hline $\mathrm{C} 0$ & 8 & 8 & 1 & & \\
\hline $\mathrm{C} 1$ in small amount of dot & 1 & 0 & 0 & & \\
\hline C1 with dot & 1 & 2 & 0 & & \\
\hline $\mathrm{C} 2$ & 0 & 0 & 2 & & \\
\hline $\mathrm{C} 3$ & 0 & 0 & 2 & & \\
\hline $\mathrm{C} 4$ & 0 & 0 & 2 & & \\
\hline $\mathrm{C} 5$ & 0 & 0 & 3 & & \\
\hline P opacity degree & & & & 31.58 & 0.0001 \\
\hline $\mathrm{P} 0$ & 10 & 9 & 0 & & \\
\hline $\mathrm{P} 1$ & 0 & 1 & 0 & & \\
\hline $\mathrm{P} 2$ & 0 & 0 & 1 & & \\
\hline $\mathrm{P} 3$ & 0 & 0 & 4 & & \\
\hline P4 & 0 & 0 & 5 & & \\
\hline
\end{tabular}

C2, C3, C4 and C5 in group A. There were 8 cases of $\mathrm{C} 0$, no cases of $\mathrm{C} 1$ with small amount of dot, 2 cases of $\mathrm{C} 1$ with dot, and no cases of C2, C3, C4 and C5 in group B. There was 1 case of $\mathrm{C} 0,2$ cases of $\mathrm{C} 2,2$ cases of $\mathrm{C} 3,2$ cases of $\mathrm{C} 4$ and 3 cases of $\mathrm{C} 5$, no case of $\mathrm{C} 0$ in group $\mathrm{C}$. Compared with groups $\mathrm{A}$ and $\mathrm{B}$, opacity degree in group $\mathrm{C}$ was higher $(\mathrm{P}<0.05)$. In the classification of opacity degree of $\mathrm{P}$, there were 10 cases of $\mathrm{P} 0$, no case of $\mathrm{P} 1, \mathrm{P} 2, \mathrm{P} 3$ or $\mathrm{P} 4$ in group $\mathrm{A}$.
There were 9 cases of $\mathrm{P} 0,1$ case of $\mathrm{P} 1$, no case of $\mathrm{P} 2, \mathrm{P} 3$ and $\mathrm{P} 4$ in group B. There was no case of $\mathrm{P} 0$ or $\mathrm{P} 1,1$ case of $\mathrm{P} 2$, 4 cases of $\mathrm{P} 3$ and 5 cases of $\mathrm{P} 4$ in group $\mathrm{C}$. Compared with group $\mathrm{A}$ and $\mathrm{B}$, the opacity degree of $\mathrm{P}$ was higher in group $\mathrm{C}$ $(\mathrm{P}<0.05)$ (Table III).

Expression levels of miR-34a and mRNA of SIRT1 and P53 in the three groups 


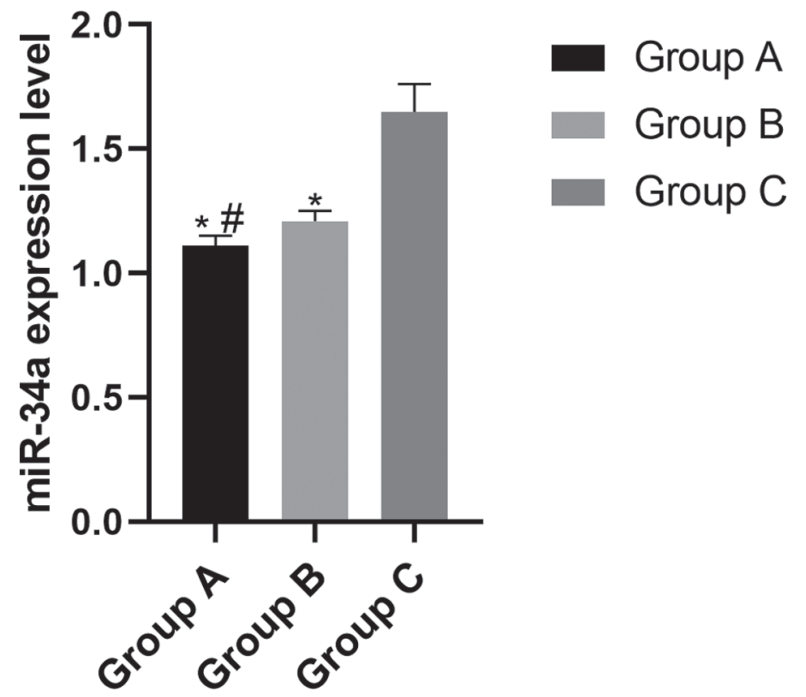

Figure 1. Comparison of miR-34a expression level in the three groups. qCPR was used to detect the expression level of miR-34a. The expression level of miR-34a in group $C$ was significantly higher than that in group A and group $B$ $(\mathrm{P}<0.05)$, while that in group $\mathrm{B}$ was significantly higher than that in group $\mathrm{A}$ $(\mathrm{P}<0.05)$. ${ }^{*} \mathrm{P}<0.05$, compared with group $\mathrm{C}$; $\mathrm{P}<0.05$ compared with group $\mathrm{B}$.

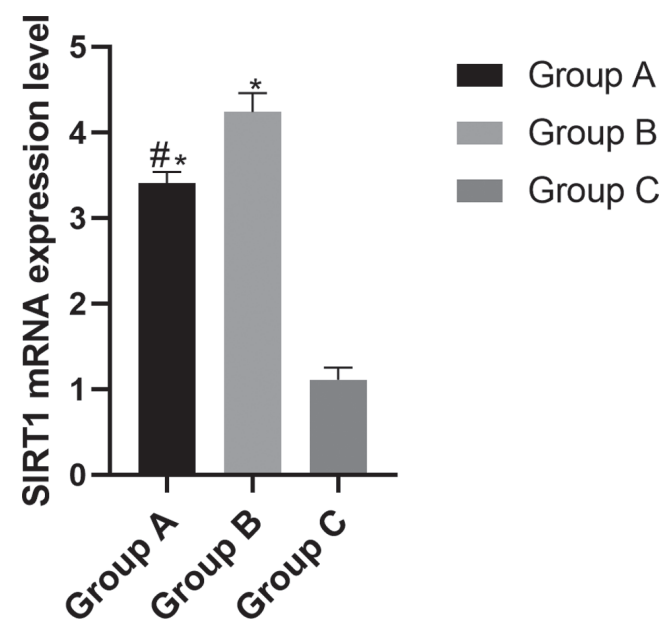

Figure 2. Comparison of mRNA expression level of SIRT1 in the three groups qCPR was used to detect the mRNA expression level of SIRT1. The mRNA expression level of SIRT1 in group B was significantly higher than that in group $\mathrm{A}$ and group $\mathrm{C}(\mathrm{P}<0.05)$, while that in group $\mathrm{A}$ was significantly higher than that in group $\mathrm{B}$ and group $\mathrm{C}(\mathrm{P}<0.05)$. ${ }^{*} \mathrm{P}<0.05$, compared with group $\mathrm{C}$; ${ }^{\#} \mathrm{P}<0.05$, compared with group $\mathrm{B}$.

Expression level of $\mathrm{miR}-34 \mathrm{a}$ in the three groups. The expression levels of miR-34a in group A, B and C were (1.11 \pm 0.04$)$, $(1.21 \pm 0.05)$ and $(1.65 \pm 0.11)$, respectively. The expression level of miR-34a in group $\mathrm{C}$ was significantly higher than that in group $\mathrm{A}$ and group $\mathrm{B}(\mathrm{P}<0.05)$, while the expression level in group $\mathrm{B}$ was significantly higher than that in group $\mathrm{A}(\mathrm{P}<0.05)$ (Fig. 1).

mRNA expression level of SIRT1 in the three groups. The mRNA expression levels of SIRT1 in group A, B and C were (3.41 \pm 0.13$),(4.24 \pm 0.22)$ and $(1.11 \pm 0.14)$, respectively. The mRNA expression level of SIRT1 in group B was significantly higher than that of group A and group $\mathrm{C}(\mathrm{P}<0.05)$, while the expression level of group A was significantly higher than that of group $\mathrm{B}$ and group $\mathrm{C}(\mathrm{P}<0.05)$ (Fig. 2).

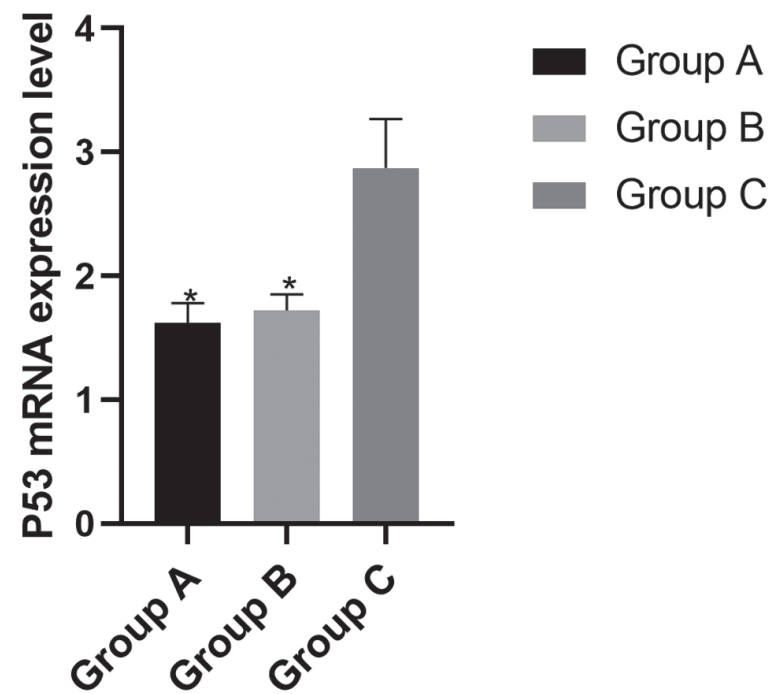

Figure 3. Comparison of mRNA expression level of P53 in the three groups The mRNA expression level of P53 was detected by qPCR. The mRNA expression level of P53 in group A and B were far lower than those in group C $(\mathrm{P}<0.05)$, and there was no difference between groups $\mathrm{A}$ and $\mathrm{B}(\mathrm{P}>0.05)$. ${ }^{*} \mathrm{P}<0.05$, compared with group $\mathrm{C}$.

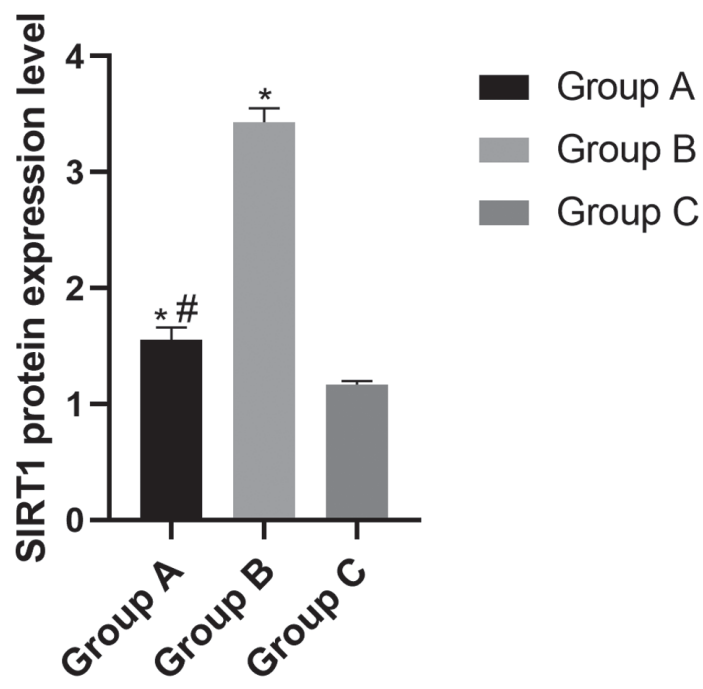

Figure 4. Comparison of protein expression level of SIRT1 before and after treatment in the three groups by western blotting to analyze protein expression level of SIRT1. The protein expression level of SIRT1 in group B was significantly higher than that of group $\mathrm{A}$ and group $\mathrm{C}(\mathrm{P}<0.05)$, while the level of group $\mathrm{C}$ was significantly lower than that of group $\mathrm{A}(\mathrm{P}<0.05)$, and there was no difference between group $\mathrm{B}$ and $\mathrm{C}(\mathrm{P}>0.05) .{ }^{*} \mathrm{P}<0.05$, compared with group $\mathrm{C} ;{ }^{\#} \mathrm{P}<0.05$, compared with group $\mathrm{B}$.

mRNA expression level of P53 in the three groups. The mRNA expression levels of P53 in group A, B and C were (1.62 \pm 0.16$)$, $(1.72 \pm 0.13)$ and $(2.87 \pm 0.40)$, respectively. The mRNA expression level of P53 in group A and B was significantly lower than that of group $\mathrm{C}(\mathrm{P}>0.05)$ (Fig. 3).

\section{Expression levels of SIRT1 and P53 in the three groups}

Protein expression level of SIRT in the three groups. The protein expression level of SIRT in group A, B and C were $(1.55 \pm 0.11),(3.43 \pm 0.12)$ and $(1.17 \pm 0.14)$, respectively. The level of SIRT in group B was significantly higher than that of 
Table IV. Rates of lens epithelial cell apoptosis in the three groups $(n=10)$.

\begin{tabular}{lllll}
\hline Groups & Group A & Group B & Group C & F \\
\hline Apoptosis rate $(\%)$ & $6.35 \pm 0.36^{\mathrm{a}}$ & $6.45 \pm 0.33^{\mathrm{a}}$ & $16.07 \pm 1.36$ & 447.90
\end{tabular}

${ }^{\mathrm{a}} \mathrm{P}<0.05$, compared with group $\mathrm{C}$.

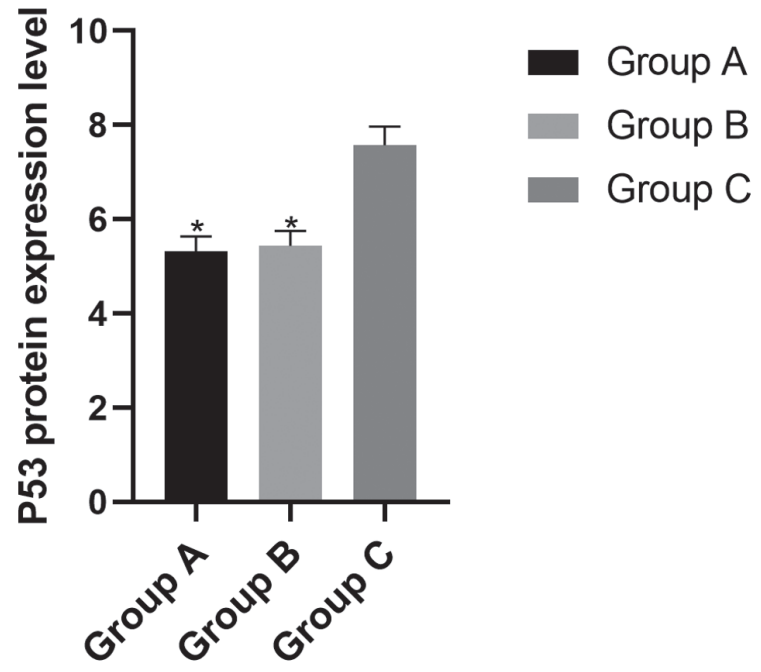

Figure 5. Comparison of protein expression level of P53 in the three groups before and after treatment by western blotting was used to analyze protein expression level of P53. The protein expression level of P53 in group A and B was significantly lower than that of group $\mathrm{C}(\mathrm{P}<0.05)$, while there was no difference between group $\mathrm{A}$ and $\mathrm{B}(\mathrm{P}>0.05)$. There was no difference between group $\mathrm{B}$ and $\mathrm{C}(\mathrm{P}>0.05)$. ${ }^{*} \mathrm{P}<0.05$, compared with group $\mathrm{C}$.

group $\mathrm{A}$ and group $\mathrm{C}(\mathrm{P}<0.05)$, while the level in group $\mathrm{C}$ was significantly lower than that of group A $(\mathrm{P}<0.05)$ (Fig. 4).

Protein expression level of P53 in the three groups. The protein expression level of P53 in groups A, B and C were (5.31 \pm 0.32$)$, $(5.44 \pm 0.31)$ and $(7.57 \pm 0.40)$, respectively. The protein expression level of P53 in group A and B was significantly lower than that in group $\mathrm{C}(\mathrm{P}<0.05)$, while there was no difference between groups $\mathrm{A}$ and $\mathrm{B}(\mathrm{P}>0.05)$ (Fig. 5).

Comparison of apoptosis rates of lens epithelial cells in the three groups. The level of apoptosis of P53 in groups A, B and C were $(6.35 \pm 0.36) \%,(6.45 \pm 0.33) \%$, and $(16.07 \pm 1.36) \%$, respectively. The protein expression level of P53 in group A and B was significantly lower than that in group $\mathrm{C}(\mathrm{P}<0.05)$, while the apoptosis rate of group $\mathrm{A}$ and $\mathrm{B}$ showed no difference $(\mathrm{P}>0.05)$ (Table IV).

\section{Discussion}

Cataract is the leading cause of blindness. Although cataract surgery has a high success rate, it still cannot meet the huge demand for treatment. At present, there is no effective drug to treat cataract, so we need to find targeted drugs. While miR-34a has been found to have an effect on human lens epithelial cells, making its pathogenesis in cataract an important research direction (13). In this study, the expression of miR-34a in cataract rats and its related mechanism were studied through a rat model.

The severity of cataract opacity was positively correlated with the level of miR-34a. Wu et al (6) also found in their study that miR-34a was highly expressed in cataract lens epithelial cells, which was higher than that in lucent lens. Therefore, we analyzed the opacity of the lens and the expression level of miR-34a in rats. The results showed that the opacity degree of $\mathrm{N}, \mathrm{C}$ and $\mathrm{P}$ in group $\mathrm{C}$ was very high, and most cases were above N2, C2 and P2, which was significantly higher than that in group A and group B. Moreover, the level of miR-34a in the lens of mice in group $\mathrm{C}$ was much higher than that in group $\mathrm{A}$ and group $\mathrm{B}$, while the level in group A was significantly lower than that in group B, which was similar to the results of the above experiments. Thus, miR-34a was highly expressed in cataract and might increase with age.

SIRT1 is a class III nad ${ }^{+}$dependent protein deacetylase that acts on programmed cell death, regulation of gene expression, DNA repair and aging mechanisms, regulates DNA stability and ensures cell survival. SIRT1 plays an important role in the self-renewal and aging of eye stem cells and is associated with various age-related eye diseases. In human eyes, gene expression of SIRT1 in lens epithelium and retina of senile cataract patients has been detected $(13,14)$. Studies have revealed that miR-34a can inhibit the expression of SIRT1, and SIRT1 can upregulate the expression of Nrf2 and activate the Nrf2/antioxidant response element (ES) pathway to protect cells from oxidative stress. When miR-34 binds to the 3'-untranslated region (utr) of SIRT1, the downregulation of SIRT1 leads to an increase in acetylation of P53 that mediates cell cycle and apoptosis. There was a positive feedback between P53 and miR-34a (15-17). P53 is a transcription factor whose main function is to regulate the cell life cycle by controlling the expression of multiple genes, thus promoting apoptosis $(18,19)$. Ji et al (20) found that P53 could regulate the cellular differentiation genes in the lens by regulating $\alpha \mathrm{A}-$ and $\beta \mathrm{A} 3 / \mathrm{a} 1$-crystallin genes. Therefore, both SIRT1 and P53 can be used as indicators for cataract detection. In this study, the expression of SIRT1 and P53 were detected from the perspective of mRNA and protein levels, and the apoptosis was also detected. The results showed that the mRNA and protein expression level of SIRT1 in group C were significantly lower than those in group A and B, while the P53 level in group $\mathrm{C}$ was higher than those in group $\mathrm{A}$ and $\mathrm{B}$, and the level of apoptosis was also significantly higher than those in group A and B. Kondo et al (21) found in animal models that SIRT1 could regulate eye aging and protect eye tissues from oxidative stress, and the increase in its level could 
prevent age-related cataracts. In the study of Lu et al (22), it was pointed out that P53 was at a higher level in age-related cataracts and could aggravate cataracts through increasing the apoptosis of lens epithelial cells. Zheng and Lu (23) demonstrated that the expression of SIRT1 could increase when P53 was suppressed. Yan et al (24) found that there were mutual effects between miR-34a and SIRT1/P53 signals, and miR-34a could decrease SIRT1 protein level and lead to the increase of P53. These results were similar to the results of this study. From the above results, it can be concluded that there is a negative feedback relationship between SIRT1 and P53. In addition, the level of SIRT1 decreased and P53 increased in the cataract. miR-34a, on the other hand, increases the expression of P53 by decreasing the level of SIRT1, leading to increase of apoptosis in the lens, which further aggravates the cataract.

This study relates to the effects of miR-34a on some related genes and their proteins, and extrapolated its impact on age-related cataracts based on these signaling pathways. However, it does not involve more specific molecular mechanisms, such as the impact of miR-34a on SIRT1 and P53. Thus, furter study is necessary.

In conclusion, the upregulation of miR-34a expression level is related to cataract occurrence in rats, which may be caused by regulation of SIRT1/P53 pathway. Therefore, the development of drugs related to cataract can be studied as a new target for miR-34a.

\section{Acknowledgements}

Not applicable.

\section{Funding}

No funding was received.

\section{Availability of data and materials}

The datasets used and/or analyzed during the current study are available from the corresponding author on reasonable request.

\section{Authors' contributions}

CX wrote the manuscript. CX and JJ conceived and designed the study. CX and RS were responsible for the collection and analysis of the experimental data. JJ and RS interpreted the data and drafted the manuscript. CX and RS revised the manuscript critically for important intellectual content. All authors read and approved the final manuscript.

\section{Ethics approval and consent to participate}

The study was approved by the Ethics Committee of The Affiliated Yantai Yuhuangding Hospital of Qingdao University (Yantai, China).

\section{Patient consent for publication}

Not applicable.

\section{Competing interests}

The authors declare that they have no competing interests.

\section{References}

1. Chien KH, Chen SJ, Liu JH, Chang HM, Woung LC, Liang CM, Chen JT, Lin TJ, Chiou SH and Peng CH: Correlation between microRNA-34a levels and lens opacity severity in age-related cataracts. Eye (Lond) 27: 883-888, 2013.

2. Fan F, Zhuang J, Zhou P, Liu X and Luo Y: MicroRNA-34a promotes mitochondrial dysfunction-induced apoptosis in human lens epithelial cells by targeting Notch2. Oncotarget 8: 110209-110220, 2017.

3. Asuthkar S, Velpula KK, Chetty C, Gorantla B and Rao JS: Epigenetic regulation of miRNA-211 by MMP-9 governs glioma cell apoptosis, chemosensitivity and radiosensitivity. Oncotarget 3: 1439-1454, 2012.

4. Leung AK and Sharp PA: MicroRNA functions in stress responses. Mol Cell 40: 205-215, 2010.

5. Noguchi S, Mori T, Otsuka Y, Yamada N, Yasui Y, Iwasaki J, Kumazaki M, Maruo K and Akao Y: Anti-oncogenic microRNA-203 induces senescence by targeting E2F3 protein in human melanoma cells. J Biol Chem 287: 11769-11777, 2012.

6. Wu C, Lin H, Wang Q, Chen W, Luo H, Chen W and Zhang H: Discrepant expression of microRNAs in transparent and cataractous human lenses. Invest Ophthalmol Vis Sci 53: 3906-3912, 2012.

7. Chen Q, Yang F, Guo M, Wen G, Zhang C, Luong A, Zhu J, Xiao Q and Zhang L: miRNA-34a reduces neointima formation through inhibiting smooth muscle cell proliferation and migration. J Mol Cell Cardiol 89A: 75-86, 2015.

8. Hu Y, Pu Q, Cui B and Lin J: MicroRNA-34a inhibits tumor invasion and metastasis in gastric cancer by targeting Tgif2. Int $\mathrm{J}$ Clin Exp Pathol 8: 8921-8928, 2015.

9. Wang B, Li D and Kovalchuk O: p53 Ser15 phosphorylation and histone modifications contribute to IR-induced miR-34a transcription in mammary epithelial cells. Cell Cycle 12: 2073-2083, 2013.

10. Lin TJ,Peng CH, Chiou SH, Liu JH, Lin C-W, Tsai CY, Chuang JH and Chen SJ: Severity of lens opacity, age, and correlation of the level of silent information regulator T1 expression in age-related cataract. J Cataract Refract Surg 37: 1270-1274, 2011.

11. Yu X, Zheng H, Chan MT and Wu WKK: MicroRNAs: New players in cataract. Am J Transl Res 9: 3896-3903, 2017.

12. Chylack LT Jr, Wolfe JK, Singer DM, Leske MC, Bullimore MA, Bailey IL, Friend J, McCarthy D and Wu SY; The Longitudinal Study of Cataract Study Group: The lens opacities classification system III. Arch Ophthalmol 111: 831-836, 1993.

13. Xiang W, Lin H, Wang Q, Chen W, Liu Z, Chen H, Zhang $\mathrm{H}$ and Chen W: miR-34a suppresses proliferation and induces apoptosis of human lens epithelial cells by targeting E2F3. Mol Med Rep 14: 5049-5056, 2016.

14. Mimura T, Kaji Y, Noma H, Funatsu H and Okamoto S: The role of SIRT1 in ocular aging. Exp Eye Res 116: 17-26, 2013.

15. Li QL, Zhang HY, Qin YJ, Meng QL, Yao XL and Guo HK: MicroRNA-34a promoting apoptosis of human lens epithelial cells through down-regulation of B-cell lymphoma-2 and silent information regulator. Int J Ophthalmol 9: 1555-1560, 2016.

16. Huang K, Huang J, Xie X, Wang S, Chen C, Shen X, Liu P and Huang H: Sirt1 resists advanced glycation end products-induced expressions of fibronectin and TGF- $\beta 1$ by activating the Nrf2/ARE pathway in glomerular mesangial cells. Free Radic Biol Med 65: 528-540, 2013.

17. Yamakuchi M, Ferlito M and Lowenstein CJ: miR-34a repression of SIRT1 regulates apoptosis. Proc Natl Acad Sci USA 105: 13421-13426, 2008.

18. López Valverde G, Garcia Martin E, Larrosa Povés JM, Polo Llorens V, Fernández Mateos J, Pablo Júlvez LE and González Sarmiento R: Study of association between pre-senile cataracts and the polymorphisms rs2228000 in XPC and rs1042522 in p53 in Spanish population. PLoS One 11: e0156317, 2016.

19. Volker M, Moné MJ, Karmakar P, van Hoffen A, Schul W, Vermeulen W, Hoeijmakers JH, van Driel R, van Zeeland AA and Mullenders LH: Sequential assembly of the nucleotide excision repair factors in vivo. Mol Cell 8: 213-224, 2001. 
20. Ji WK, Tang XC, Yi M, Chen PQ, Liu FY, Hu XH, Hu WF, Fu SJ, Liu JF, Wu KL, et al: p53 directly regulates $\alpha A-$ and $\beta A 3 / \mathrm{A} 1$-crystallin genes to modulate lens differentiation. Curr Mol Med 13: 968-978, 2013.

21. Kondo A, Goto M, Mimura T and Matsubara M: Silent information regulator $\mathrm{T} 1$ in aqueous humor of patients with cataract. Clin Ophthalmol 10: 307-312, 2016.

22. Lu B, Christensen IT, Ma LW, Wang XL, Jiang LF, Wang CX, Feng L, Zhang JS and Yan QC: miR-24-p53 pathway evoked by oxidative stress promotes lens epithelial cell apoptosis in age-related cataracts. Mol Med Rep 17: 5021-5028, 2018.

23. Zheng $\mathrm{T}$ and $\mathrm{Lu} \mathrm{Y}$ : Upregulation of Sirtl protects lens epithelial cells in oxidative conditions and cataract formation in humans. Invest Ophthalmol Vis Sci 52: 5291-5291, 2011.
24. Yan S, Wang M, Zhao J, Zhang H, Zhou C, Jin L, Zhang Y, Qiu X, Ma B and Fan Q: MicroRNA-34a affects chondrocyte apoptosis and proliferation by targeting the SIRT1/p53 signaling pathway during the pathogenesis of osteoarthritis. Int J Mol Med 38: 201-209, 2016.

(c) (i) $(9)$ This work is licensed under a Creative Commons Attribution-NonCommercial-NoDerivatives 4.0 International (CC BY-NC-ND 4.0) License. 